\title{
日本茶業技術協会の歩み
}

\author{
元農林水産省茶業試験場 \\ 中川致之 \\ (平成25年 8 月 13 日受理)
}

\section{The History of Japanese Society of Tea Science and Technology}

\author{
Muneyuki Nakagawa \\ The Former Director of the National Research Institute of Tea
}

\section{1 歴 史}

第二次大戦中, さらに, 戦後の食糧難の時 代は, 食糧の生産が優先され茶は不急作物で あったため, 茶畑は芋畑などに変換されて, 終戦の昭和 20 年から 23 年頃にかけては荒茶生 産量が激減していた。一方, 戦後の日本の飢 餓状態を緩和するため, 連合軍が主要食糧を 放出し, その見返り物質の一つとして茶を指 定してきたので, 茶の貿易再開がいち早く行 われた。

そのような時であった昭和 22 年に茶業技術 協会が創立されたが，その経緯については, 出発点の段階から相談に加わり, 昭和31年か ら10年以上にわたり本会の副会長を務められ た元埼玉県茶業研究所長の太田義十氏が, 茶 業技術協会創立 20 周年記念, 茶業研究報告別 冊資料第 3 号 $^{1)}$ に, 詳しく書かれている。そ れによると, 戦後の混乱のなかで茶業の再建 を図るべく, 技術者による協会設立の必要性 が, 有志の間で話題になっていたが, 創立に 要する資金調達が大きな問題点であったとさ れる。

たまたま, 当時農林省食品局農産食品課の 佐藤鎯蔵技官の努力によって農産品輸出振興
の見地から茶業復興の重要性が認められ，茶 業振興を目的とする協会に対し助成の見込み があるという情報が示され，その結成を期す ることになった。この舞台裏での日本茶業会 の久木元猛氏の働きを忘れてはならないと太 田義十氏は記述している。

そこで, 昭和 22 年 8 月 13 日埼玉県茶業研究 所に農林省, 全国農業会, 日本茶業会, 埼玉 県茶業研究所の有志が集まり, 日本茶業会の 久木元猛氏のもとで立案中の協会設立趣意 書, 事業計画書, 会則, 創立の時期, 方法等 について協議検討を加えた。そして, それを 急遽,各都府県の茶業技術関係の要職にある 人達に送って発起人としての参加を求め, そ の承諾を得て発起人創立総会に切り替え, 昭 和 22 年 9 月 11 日に会則を制定，暫定役員を選 任して茶業技術協会が誕生した。さらに，同 年11月, 日本茶業会主催の第 1 回全国製茶品 評会が静岡市で開催されたのを機として, 11 月19日に全国から180人が参加して第 1 回総 会を開催し, 理事（各都府県から 1 名、も しくは、若干名), 顧問, 参与（森田豊寿氏、 大石八治氏ら政治家も含む）を選任した。引 き続き理事会を開き, 会長は専任茶業試験場 長の任命を待って充てるため空席とし, 本会 
の結成に尽力された久木元猛氏を副会長，会 長代理に選任した。

本会は, 当初「茶業技術協会」と称して発 足したが，翌年の第 2 回総会で「全国茶業技 術協会」に改称した。当時米軍占領下であっ たため日本という名称は控えて全国にしたも のであるとされる。しかし, 講和条約締結後 の昭和 27 年10月の総会で鳥井秀一理事の提案 により満場一致で現在の「日本茶業技術協会」 を名乗ることになった。また，昭和 24 年 3 月 には，茶業技術協会は，農林省外郭団体に指 定され公職に該当することになると書かれて いる。

昭和 24 年 4 月加藤博氏が農林省茶業試験場 長に任命されたので，5月に理事の書面決議 により欠員中の本会会長に選任された。この 頃会は経理面の窮迫に苦しみ, 業界の援助を 求めるため, 昭和 25 年 2 月に参議院議員の森 田豊寿氏を会長に選任して打開を図ったが, 予期の成果を収めることはできなかった。結 局, 他力本願ではなく, 会員自らの力によっ て会を運営しょうという気運が盛りあがり, 昭和26年10月に役員を改選し, 加藤博会長, 久木元猛副会長，専務理事に静岡県茶販連鈴 木正吉氏の現体制に近い形になった。

事務所は, 最初は仮に農林省農政局農産課 内に置かれ，昭和24年に正式の住所を全販連 とし，事務はそれまで同様農産課で取り扱っ たが, 昭和 28 年以降は農林省茶業試験場内に 置かれた。しかし，太田義十氏が昭和44年7 月前記の原稿を書かれた頃には各種の関係資 料が保管されておらず苦労したと後記に書か れている。

昭和 43 年 2 月, 多年会長職を務められた加 藤博氏が茶業試験場を定年退職される直前に 緊急理事会を開催し, 以後, 会長は国立茶業 試験場の場長を充てることを可決し，その職 にあるものが代々会長に選任されてきたが, 筆者が国立茶業試験場長であった昭和59年に 突如現職場長が関連外部団体の長を兼任する
のは好ましくないという農林水産技術会議の 通達により，以降OBが会長に選任されるこ とになった。それまで準公務扱いであった茶 業技術協会の行事運営等にとって後退せざる を得ない点が生じたのは否めない。

\section{2 茶業技術の開発，改善，及び，情報交換 活動の経過}

\section{1 ) 機関誌}

昭和 23 年に刊行物として「全国茶業技術協 会彙報」が発刊されたが，昭和 27 年に第 12 号 をもって中止された。

また，昭和 24 年 2 月，農林省茶業試験場の 機関誌として「茶業技術研究・第 1 号」が発 刊されるに当たって全国茶業技術協会は，念 願であった同会の学術専門誌として利用させ てもらえることを会員と共に慶びたいという 声明を出した。会員の寄稿については，第 2 号以降に国立茶業試験場内牧風会を通じて行 うこととした。

しかし, 昭和 28 年には, 日本茶業技術協会 加藤博会長が, 昨年 3 月から「茶業技術研究」 に，有志会員の研究報文その他を追加して全 会員に配布してきたが，近年研究発表会にお ける講演数の増加より推して, 各茶業研究機 関に在職せらるる会員各位の旺盛な研究活動 を思い, 研究成果を発表する独自の機関誌を 持つべき時期に至ったと述べ ${ }^{2}$ ，「茶業研究 報告・第 1 号」が誕生し，おおむね，年 2 回 の刊行で今日に至っている。

ところで, 茶業研究報告に掲載される論文 は，日本茶業技術協会が日本学術会議の広報 協力団体として扱われていたため，学会誌揭 載の論文より 1 ランク下のB ランクに位置づ けられていた。そこで，平成 7,8 年頃，日 本茶業技術協会は学術団体への昇格に必要な 条件を満たしていることを明らかにする資料 を添えて昇格の申請を行い承認されたので, 茶業研究報告掲載の論文は学会誌掲載の論文 と同等の評価になった。 


\section{2) 研究発表会}

この項目については, 上記の茶業研究報告 の協会創立 20 周年 ${ }^{1)}, 30$ 周年 ${ }^{3)}, 50$ 周年記念 資料 ${ }^{4)}$ にある年表, 及び, 定期刊行の本会 記事, 会報によるところが多い。

昭和 22 年 11 月の第 1 回全国製茶品評会に合 わせて, 茶業技術協会の第 1 回総会と研究発 表会が行われた。以降全国製茶品評会, 全国 茶業者大会, 全国扮茶まつりと名称は変わる が昭和58年までは, ほとんど, 毎年, 秋の全 国の茶業者の大会の時に総会と研究発表会が 開催された。研究発表会の講演要旨は昭和 23，24，25年に関しては，前記彙報に掲載さ れている。第 1 回の研究発表会の要旨は彙報 の第 1 号が独立行政法人農業・食品産業技術 総合研究機構野菜茶業研究所の図書室に保存 されていないため, 確認できないが彙報第 1 号に掲載されているのではなかろうかと思わ れる。

昭和 28 年以降は, 各都府県の茶業研究機関 の技術者が多数出席して, 毎年 2 月頃開催さ れる茶試験研究打合せ会議（後に茶専門別検 討会議に変わる）の時に育種, 栽培, 製造な ど各部門の個別研究発表会を, 毎年秋に開催 される茶業者全国大会の時に題目数をしぼっ たシンポジウム形式のような研究発表会を行 うという形で昭和58年まで継続されてきた。

しかし, 昭和 56 年, 第 2 次臨調が設置され ると, 農林水産省の試験研究機関の数が多す ぎると指摘され, 農林水産技術会議は試験研 究機関の体制や調整機能の検討を行うことに なった。その結果, 茶業試験場は野菜試験場 と統合することになった。それに先立ち, 農 林水産技術会議は, 従来, 専門場所が行っ てきた専門別総括検討会議（ブロック会議） は, 個別の研究領域内の検討に終始している ので, むしろ, 地域の総合農業振興を重要視 すべきであるという理由で, 茶業に関する試 験研究の調整は茶の生産のある地域農業試験 場の茶業部会で行う形にした。そのため, 茶
を生産する各都府県の茶業試験研究機関の多 数の技術者が一堂に会して国立茶業試験場で 検討を行う，いわゆるブロック会議は基本的 には廃止して, 国立の茶業試験場, 後継の野 菜・茶業試験場は地域農業試験場の茶業部会 に協力することになった。この改革は, 農林 水産省が地方農政局の立場維持のため, それ と連携して地域農業試験場の強化を図ったも のと思える。やがて、野菜・茶業試験場の後 継の野菜茶業研究所でも全国的な茶業専門分 野別研究会等が行われるようになったが, 多 数の都府県茶業試験研究機関の技術者にとっ ては, 一同に会して専門別に研究の検討を行 う機会がなくなったので, 茶業分野の専門知 識等の獲得にマイナスになった。また，それ まで, ブロック会議とセットで行われていた 日本茶業技術協会の個別研究会は総会も併せ 11 月に, 昭和 59 年から 62 年にかけては金谷の 茶業試験場, または, 野菜・茶業試験場金谷 で行われるように変更された。さらに，昭和 63年から平成21年までは大体島田市にある宮 美殿で，毎年行われるように変わった。ただ し, 平成 22 年は国際お茶学術会議との共催で 10 月に静岡市グランシップ，23年は宇治，平 成24年は島田市で会場を宮美殿からプラザお おるりに換えて11月に行われている。

したがって, 研究発表会はブロック会議と いう公務とセットになっていた時と異なり， 自由参加のような形になったため, 府県によ っては出張にならないなど影響を受けざるを 得なかった。

研究発表会の講演要旨集は, 昭和 27 年10月 から, 別冊で刊行され, 当初はごく簡略な文 章だけの内容であったが, 段々に図面等も加 えるようになり, 昭和63年以降は文章, 図表, それぞれ 1 頁ずつで研究発表の概略を知るこ とができる茶業研究報告別冊の形で, 刊行さ れるようになった。 
3 ) 国際茶研究シンポジウム

1991年 8 月実施された国際茶研究シンポジ ウム (International Symposium on Tea Science) では, 日本茶業技術協会は同シンポジウム組 織委員会とともに主催者になった。この国際 シンポジウムには, 海外19カ国から100名程 の出席者を始めとして, 予想をはるかに上回 る参加者があり, 茶の薬理, 栄養学に関する 44 課題を筆頭に, 計160課題の研究発表があ り大変盛会であった。また, このシンポジウ ムを機に茶の機能性に関する研究が益々進展 した。

\section{4) 特別刊行物}

茶業技術協会は，創立 $20 ， 30 ， 50$ 周年記念 に別冊資料 $3,4,5$ 号を刊行し, 協会の歩み (年表), 役員の変遷, 感謝状, 功労賞, 技術 賞受賞者とその業績を紹介した。また， 3 号 には,「大茶樹・由緒ある茶園」の写真と説明, 4 号には, 当時南九州の茶栽培にとって重要 な問題であったチャの裂傷型凍害に関する研 究報告集を掲載した。

その他, 随時, 啓蒙や知識普及活動の一つ として, 昭和 32 年には, 1955年ニューヨーク 科学アカデミーで行われた茶の薬物学, 生理 学, 及び, 心理学的効果に関する討論会記録 の林屋新一郎氏による翻訳を別冊資料第 1 号 として刊行した。昭和45年には, 酒戸弥二郎 教授の編集によって, 当時の茶の化学研究の 第一線の研究者がそれぞれの専門分野の研究 成果をまとめたものを別冊資料第 2 号として 刊行した。

昭和33年には, 茶業用語の統一を図るため 「茶業用語集」を発刊, 配布した。平成10年 には，茶業技術協会創立50周年記念事業の一 貫として「茶の科学用語辞典」・第 1 版を発 刊した。さらに, 好評であったため 2007 年(平 成19年) に改訂第 2 版を刊行した。

\section{3 表彰}

日本茶業技術協会は，茶業技術の向上に関 して, 功労者, 及び, 技術開発者の顕彰事業 を行っている。表彰規程によると, 功労賞は, 各年度 5 名程度を原則として，多年にわたり 茶業関係の研究, 行政, 事業等に従事し, 茶 業の振興に顕著な功績のあった会員に授与す る。技術賞は, 本会の会員で, 茶業技術に関 して優れた研究, 並びに, 開発を行った者に 与えるとされる。平成 24 年末までに, 273 名 に功労賞が，51名に技術賞が授与された。

その他, 会長退任者に対する感謝状の贈呈 も 9 人に達している。

\section{4 現状}

茶業技術協会の会員数は, 初期の時代に関 しては記録が残っていないため不明である が，記録がある昭和46年頃から58年末頃まで は1,166名の時もあり, 大体千人を超えてい た。しかし，その後は，年々減少して平成 23 年末には631名となり, 健全な運営が危ぶま れる状態になっている。

この原因は，種々考えられるが，まず，基 本的には近年深刻化している日本の茶業の不 況がある。戦後の復興期や生産が伸びていた 成長期には生産者や茶商の勉強意欲も旺盛で あったが，今では今後の茶業経営に熱を失っ

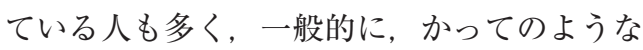
意気込みが感じられない。

日本茶業技術協会の会員は, 現在は, 国, 及び, 都府県の茶試験研究機関に勤務する技 術者が中心になっている。これらの機関にお いては, 高度経済成長期には施設等の拡大, 増員が行われたが，近年は一転して整理，統 合等の合理化が進められ技術者の数も減少し ている。たとえば, 国にしても野菜試験場と の統合, 独立行政法人化と変わり, 著しい定 員削減が行われた。専門別総括検討会議もな くなり, 都府県の多くの技術者との交流の機 
会も減少した。

農協においても, 金融部門に依存して経営 を維持している状況で, 農家のための営農部 門の指導技術者等は減少しているのではない かと思われる。

会員数の減少は, 要するに, 日本茶業の構 造不況の反映が大きいと考えられる。日本の 茶業の振興を図るには, このような時にこそ 技術研究の充実が必要である。そのような認 識を関係者に浸透させいくことが必要である と思う。

一方, 種々の専門分野の学会誌が刊行され ているなかで, 日本茶業技術協会の機関誌, 茶業研究報告は, 主として茶の生産技術の研 究を揭載している。近年多くなっている茶の 保健性等に関する研究成果や一部の先端的研 究等は, それぞれ，その専門分野の学会誌, あるいは, 欧文やインターナショナルな学会 誌に投稿されるものが多い。茶業研究報告に もこのような領域の論文の投稿も取入れてい きたいところであるが, 事実上それ程期待で きないのではなかろうか。したがって，茶の 生産技術向上のための試験研究誌として活動 していくのが本命のように思う。しかし, せ めて, 資料として他の学会誌の茶関係の研究 題目と掲載誌の紹介を掲載したらどうであろ うか。

現在, 世界各国の茶の生産量, 消費量は年々 伸びているにも拘らず，日本では減少傾向で ある。国際的な消費量の増加の一因として緑 茶の保健性への注目があるといわれる。日本 の煎茶に関しては, 今後輸出増加の可能性も 考えられている。日本の農政, とくに特産物 に関しては, 従来, 外国産のものに押されて 危機に陥っている農産物のてこ入れ等, 守り 中心で進んできたが, 空しい努力に終わった ものが多かったようにも思う。国際化が進む なかでは, 内需だけでなく輸出がない限り伸 びはない。今後は, 国際競争に耐えられるも の, あるいは, 輸出の可能性のあるものを育
てていくという攻めの対策が必要であると思 う。

\section{5 謝辞}

初期の情報の一部を提供して頂いた中山仰 氏に深く感謝申し上げます。

\section{6 引用文 献}

1 ) 太田義十(1970)：茶業研究報告, 創立20 周年記念, 資料第 3 号, 昭和 45 年 9 月.

2 ) 加藤 博 (1953): 茶業研究報告, 第 1 號, 昭和 28 年 4 月.

3 ) 茶業研究報告 (1979）：創立30周年記念, 資料第 4 号，昭和 54 年 3 月.

4 ) 茶業研究報告 (2000)：創立50周年記念, 資料第 5 号，平成 12 年 9 月. 